\title{
Golgotha and the burial of Adam between Jewish and Christian tradition
} Text and monument*

\author{
JORDAN J. RYAN
}

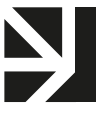

VERTAISARVIOITU

KOLLEGIALT GRANSKAD

PEER-REVIEWED

www.tsv.fi/tunnus

DOI: https://doi.org/10.30752/nj.100583

AвstRACт $•$ The curious name of Golgotha, and its translations provided by the evangelists, became a focal point for interpretation, opening the door for new Christological concepts to become affixed to it. As these novel Christological interpretations accrued around Golgotha, they would eventually crystallise, and become a fixed part of the commemoration of Jesus in Palestine. Starting with Origen, third and fourth century Christian authors strongly associate the place of Jesus's crucifixion with the burial place of Adam.

Despite the fact that, as we shall see below, Origen and other early Christian authors claim that the identification of Golgotha as Adam's burial place is a 'Hebrew' tradition, the genesis of the connection between Adam and the site of Jesus's crucifixion and its relationship to other early Jewish and Christian traditions about the location of

* The text of this article is a revision and combination of an Oslo Lecture in New Testament given at the Faculty of Theology at the University of Oslo with some portions of a presentation given at the 'Transformations in Stone' symposium at Lund University in early 2020 . The research presented here comes out of a larger project that examines the earliest Christian commemorative architecture dedicated to the life of Jesus in Palestine and the reception of traditional sites associated with the events of the Jesus's life that they enshrine, which will be published as a monograph titled From the Passion to the Church of the Holy Sepulchre: Memories of Jesus in Place, Pilgrimage, and Early Holy Sites over the
Adam's burial remain unclear. This presents us with an opportunity to examine the interface and relationship between the tradition of Adam's burial at Golgotha that appear frequently in early Christian writings of the third and fourth centuries and Jewish traditions concerning the death and burial of Adam. So doing may help to shed fresh light on Jewish-Christian relations in antiquity through the various traditions about the location of Adam's burial. Previous attempts

First Three Centuries, Reception of Jesus in the First Three Centuries 7 (London: T\&T Clark, 202 I). Thanks are due to Grant Flynn for his help with the formatting and proofreading of the manuscript. Additional thanks are due to Anders Runesson as well as Karin Zetterholm for their work in organising the aforementioned events, as well as to Wally V. Cirafesi, Rina Talgam, Henrik Gerding, Samuel Rubenson, and Katharina Keim for the rich conversations throughout the 'Transformations in Stone' symposium, which contributed to this piece. 
to address this question, though they have provided valuable insights, have been complicated by several factors, including problematic assumptions about the dates and relative chronology of the various traditions about Adam's burial, text-critical issues, and shifting scholarly perceptions that have problematised earlier understandings of the 'Jewish' or 'Christian' authorship of some of the texts. ${ }^{1}$ Our study will thus need to be attentive to these problems.

As our investigation below will reveal, we can identify several different strains of traditions about Adam's burial. Different Jewish and Christian strains of tradition locate Adam's burial I. where he was created, at an unspecified location outside Eden; 2. where he was created, which is specifically within Paradise (Eden); 3 where he was created, which is an unspecified location within Jerusalem; 4. in Jerusalem at Golgotha, where Jesus was crucified; 5 at Machpelah (Hebron, Kiryat Arba); 6. on Mount Moriah; or 7. some combination of the above traditions. The relationship between these traditions can variously be characterised in terms of reception, development, competition, response, or a combination thereof.

As our investigation will demonstrate, several of these traditions were circulating concurrently, and some sources specifically indicate an awareness of the existence of multiple competing traditions. In the fourth century, the tradition of Adam's burial at Golgotha was widely received and attested in Christian sources. However, it is also clear that the Kiryat Arba tradition was current in Jewish circles at this time, and was known to Christians as well. At some point, the Mount Moriah tradition also began to circulate. It

1 Especially the Life of Adam and Eve texts and, in older scholarship, the Cave of Treasures. is worth considering the dynamics of this competitive traditioning process. It is also important to understand the interface of the Golgotha, Kiryat Arba, and Mount Moriah traditions in connection with the Church of the Holy Sepulchre, where the traditional site of Golgotha was located and incorporated into the architecture. As we shall see, there are ways in which the Church of the Holy Sepulchre was interpreted in anti-Jewish or supersessionist modes. In fact, elements of supercessionist ideology are incorporated into the architecture itself. In light of this, it will be necessary to consider the traditional 'place' of Golgotha in the inner courtyard of the Church of the Holy Sepulchre and its role in the traditioning process as well. This is because, by situating Adam's burial on Mount Moriah, the former site of the Jewish Temple, or at Hebron, site of the Tomb of the Patriarchs, Adam's legacy could be firmly connected to specifically Jewish sites rather than the Church of the Holy Sepulchre, and the Christological connection between Jesus and Adam could be undercut.

\section{Origen and the burial of Adam at Golgotha}

Although the evangelists use the Aramaic name 'Golgotha' to refer to the place of crucifixion, and speak of it as though it was a known toponym, the name does not appear in any known Jewish sources that can be securely dated prior to the reign of Constantine. ${ }^{2}$ However, an explanation for the nomenclature of the place of crucifixion can be found in early Christian literature, in which it is frequently connected to the burial place of Adam. The earliest extant tradition connecting Golgotha to Adam can be found

2 For a classic but dated review of the material, see Jeremias I $926 \mathrm{a}$ and $1926 \mathrm{~b}$. 
in Origen's Commentary on Matthew, I 26. Since it is the earliest and most significant attestation to the tradition, it is fitting to cite it in full here. It has been preserved in a Greek fragment as well as in the Latin translation.

The Latin text in translation reads:

But the 'place of Calvary' is said not to have any expansive meaning whatever, so that he who was to die for humanity died there. For some such tradition has reached me that the body of Adam, the first man, was buried there [Calvary] where Christ was crucified so that 'just as in Adam all die, so in Christ all are made alive'; so that at that place, 'which is called the place of Calvary, that is the place of the head', the head of the human race found resurrection with all people through the resurrection of our Lord and Saviour, who suffered there and arose. (Origen, Commentary on Matthew I 26$)^{3}$

For Origen, the 'skull' is 'the head of the human race', that is, Christ. This idea clearly draws upon the concept of Jesus's supremacy depicted in terms of his being

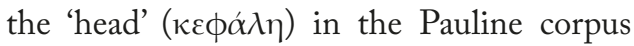
(1 Cor. Ir:3; Eph. I:22; Col. r:18). Indeed, Origen's interpretation of Golgotha is deeply rooted in Pauline Adam Christology, citing I Corinthians I5:22. This is made possible by the name of the place and Origen's connection of that name to a tradition locating Adam's burial on Golgotha. Golgotha, and its significance as the place of the crucifixion, is thus remembered in light of the Pauline tradition of Adam Christology. ${ }^{4}$

3 Translation from Heine 201 8: 740.

4 On the theological connection between the place of Adam's burial and Christ's crucifixion in early Christianity more generally, see Grypeou and Spurling 201 3: 7I-9.
The Greek fragment of this passage calls the Adamic burial tradition a 'Hebraic tradition' that has 'come down', 5 a claim that is missing from the Latin text. Scholars are understandably divided over the origin of this tradition. Some scholars have argued for a Jewish-Christian genesis. ${ }^{6}$ Bellarmino Bagatti, for example, regarded the Adamic Golgotha tradition as Jewish-Christian, particularly on the basis of evidence drawn from late-antique Adamic literature, especially the Cave of Treasures, which locates Adam's burial at Golgotha, in the 'center of the earth' (22:I23:25; see Bagatti and Testa 1978: 27-30). ${ }^{7}$ The Cave of Treasures is a Syriac text that presents a narrative centred upon major figures in Genesis from Adam and Eve to Abraham. Its story connects Adam not only to Jesus's death through Golgotha, but also Jesus's birth, since the titular cave of treasures is a cave near Paradise in which Adame deposits treasures, including gold, incense, and myrrh. These items would eventually be recovered and given to the infant Jesus by the Magi (5:I 7-I 8, 45:I 2, 46:I 2). Ignazio Mancini has likewise argued that the origin of the tradition of Adam's burial at Golgotha is JewishChristian, since it differs from the traditions about the location of Adam's burial place

5 Again, note that the Latin lacks the mention of the Hebraic origin of the tradition. However, the question as to whether the tradition that is mentioned here is of Jewish origin is valid and worth pursuing whether or not Origen explicitly identified it as handed down by Hebrews (Gk

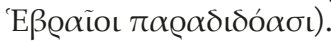

6 For example, see the discussion in Kretschmar I 987: 29-I I I (esp. I07 ff.). Somewhat more recently, see Skarsaune 2002: I 85.

7 Bagatti also discusses the Combat of Adam, but since this text is another 'life of Adam and Eve' narrative that is dependent upon the Cave of Treasures, it does not provide any new or different evidence. 


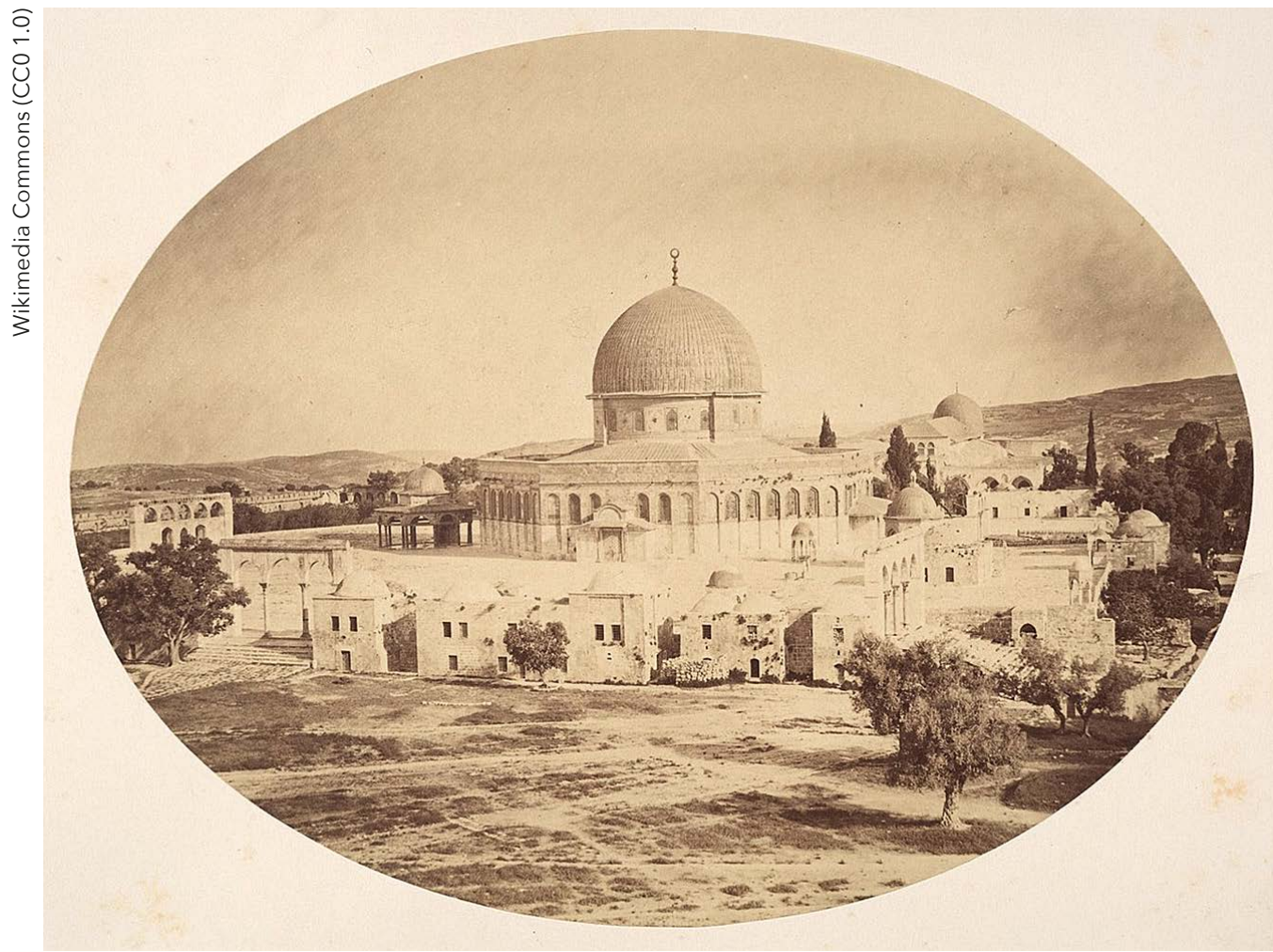

The dome of the rock on Mount Moriah, 1857. The Elisha Whittelsey Collection, The Elisha Whittelsey Fund, 1963.

preserved by 'the synagogue', by which he seems to mean rabbinic literature (Mancini I 984: I67).

However, Joan E. Taylor has presented strong arguments against the positions of Bagatti and Mancini. Arguing against Mancini, she notes that the fact that the Adamic burial tradition referenced by Origen differs from traditions seen in rabbinic literature is not evidence that it is thereby Jewish-Christian (Taylor I993: I27). Taylor also rightly observes that Bagatti's reliance on the Syriac Cave of Treasures to establish the Jewish-Christian origins of the Adamic Golgotha tradition is problematic, owing to the late date of the text and to its questionable status as a 'Jewish-Christian' text, since at best, it is a Christian text making use of an earlier Jewish source (ibid. p. I 28).
As previous scholarship has recognised, the Cave of Treasures is indeed quite late, probably dating from the fifth or sixth centuries $\mathrm{CE}$ at the earliest, ${ }^{8}$ several centuries after Origen's time. The Adamic Golgotha tradition had already become common in Christian circles by the end of the fourth century CE (see discussion below), presumably invigorated by the construction of the Church of the Holy Sepulchre. Thus, it is likely that the Cave of Treasures is a later reception of the tradition, not evidence of an

8 On the date of the Cave of Treasures, see Leonhard 2001: 25 5-88. See also Minov 2017: 1 29-229. Both authors argue effectively for a late date. Minov dates the text somewhat later than Leonhard, placing it between the middle of the sixth and first decades of the seventh centuries CE. 
earlier Jewish-Christian instantiation of the Adamic Golgotha story (cf. Leonhard 200 I: 278-80).

Taylor has argued that the Adamic Golgotha tradition could have originated from a misunderstanding by Origen (Taylor I993: I24-3I). She notes that, in Jewish tradition, rather than Golgotha, Mount Moriah or Hebron are regarded as the burial place of Adam. ${ }^{9}$ Moreover, Jewish tradition regards Mount Moriah as the axis mundi, whereas in Christian tradition it is Golgotha. This, combined with the fact that Golgotha was located under a temple dedicated to Venus in Origen's day, allowed for confusion. According to Taylor,

If we know that Jews did not believe that Adam was buried under the temple of Venus, but under Mount Moriah or Hebron, how then did Origen come to make a mistake? Origen may have confused a 'temple' (the Jewish Temple) possibly referred to by his source with the temple of Venus which had stood on the site of Golgotha since the days of Hadrian. Or else it is possible that his resiting of an event located by some Jews on the Temple Mount was polemical: it made the Adam Christology of Paul more poignant.

(Taylor I993: I30-I)

The intriguing hypothesis that the Golgotha burial tradition is a Christian reworking of an earlier Jewish tradition that Adam was buried on Mount Moriah has since been followed by other scholars (e.g. Skarsaune 2002: 205; Gonen 2003: I 23; Krewson 2017: 106). In a similar vein, Isaiah M. Gafni has recently argued that Second Temple Jewish tradition located the burial of Adam in Jerusalem (Gafni 2019: 36-7), and that the Christian

9 See also Krewson 201 7: 106. tradition of Adam's burial at Golgotha was a development of that tradition (pp. 38-42). In order to explain the existence of the tradition of Adam's burial at Hebron (Kiryat Arba) in Rabbinic literature, Gafni suggests that the Hebron tradition developed in response to the Christian siting of Adam's burial at Golgotha in Jerusalem (pp. 38-42, esp. 42).

What makes the hypotheses espoused by both Taylor and Gafni attractive and compelling is that, rather than simply viewing the existence of multiple, differing traditions about the location of Adam's burial in Jewish and Christian sources as coincidental, siloed developments, both Taylor and Gafni have instead suggested that it is preferable to understand these various traditions in relationship to one another. Moreover, both suggest that the relationship between the various traditions about Adam's burial in late antiquity can potentially be interpreted as competitive. While there is much to commend in both of these hypotheses, a clearer picture of the precise relationship between the various traditions could potentially be gained. There is a need for greater clarity concerning the relative chronology of the Adam burial traditions. Logically, if one tradition is a response to another, the tradition that is being responded to must predate the response. Moreover, as we shall see below, the earliest Jewish sources locate Adam's place of burial within Paradise, and do not identify Paradise with Jerusalem. Thus, in order to track the path and reception of the tradition of Adam's burial, we will need to examine the sources.

\section{The burial of Adam at Machpelah and Moriah} in Jewish sources

We begin with the Machpelah traditions. The burial of Adam and Eve at Machpelah at Mamre (Hebron, Kiryat Arba) is attested in b. Erub. 53a, Genesis Rabbab 58:4, 9, and 
Pirqe de Rabbi Eliezer (PRE) 20.9. It is also attested by Jerome, the celebrated Christian thinker and translator of the Vulgate Bible, who resided at Bethlehem at the tail end of the fourth century (Commentary on Matthew IV, on Matt. 27:33). ${ }^{10}$ In b. Erub. 53a (cf. b. Sotah r 3 a), there is a discussion of Machpelah. According to a tradition preserved there which is attributed to Rabbi Isaac, Hebron (where Machpelah is located) is called Kiryat Arba ('the city of four') because four couples are buried there: Adam and Eve, Abraham and Sarah, Isaac and Rebecca, and Jacob and Leah. This is essentially the same tradition as that known to Jerome, as he mentions that Adam was buried at Hebron along with Abraham, Isaac, and Jacob (Jerome's Epistles ro8.ri). Likewise, Genesis Rabbah 58:4 identifies Adam and Eve as being the first of the four righteous fathers and mothers buried at Kiryat Arba. The agreement between these sources is certainly noteworthy. However, these sources (PRE, the Babylonian Talmud, Genesis Rabbah, and Jerome) are all relatively late, postdating both Origen and the construction of the Church of the Holy Sepulchre. Intriguingly, the origin of the tradition is not entirely shrouded in mystery, since it seems to be based on the toponym Kiryat Arba, as per b. Erub. 53a. As Dieter W. van der Horst writes, the origin of this exegetical tradition is to be sought in the fact

10 On the chronology of these texts in relation to Jerome, see van der Horst 20I4: 3-4. Pieter van der Horst suggests that Targum Neofiti, which translates Gen. 23:2 as 'Sarah died in the city of the four patriarchs' might be an earlier version of the tradition (2014: $3-4$ ), but this is an inference several steps removed and far from certain. Nevertheless, van der Horst's basic point that the tradition must have been in circulation by the end of the fourth century in order for Jerome to have known it is certainly correct. that the Bible does mention the burial of the three Patriarchs and their wives in Hebron/ Kiriath-Arba (Gen. 23:1 9; 25:9; 35:27-29; 49:29-3 I), but that the explanation of this toponym as 'city of four (persons)' required one more great name (of a man or a couple) (2OI4:4).

Curiously, both the Machpelah and the Moriah traditions appear in PRE 20.11 Although $P R E$ is attributed to Rabbi Eliezer, who was a Tanna, ${ }^{12}$ the text itself is typically dated somewhere between the seventh and ninth centuries CE. ${ }^{13}$ The relevant passages are $P R E$ I2, which situates Adam's creation on the site of the Temple (cf. Genesis Rabbab I4:8), and $P R E$ 20, which depicts Adam being driven out of Eden (cf. Gen. 3:24) and residing at Mount Moriah, where he eventually dies (PRE 20.I). ${ }^{14}$ Curiously, Adam builds himself a mausoleum near (literally 'towards') Mount Moriah, and is buried there in a 'cave', which is the Cave of Machpelah (PRE 20.9). Thus, $P R E$ effectively relocates the Cave of Machpelah from Hebron to Mount Moriah (cf. Grypeou and Spurling 20I3: 9I; see also van der Horst 20I 4: 3-4).

The tradition (or traditions) of Adam's burial in PRE 20 is a curious matter, since it appears to combine both the Machpelah and Moriah traditions, and relocates Machpelah to Moriah in order to accomplish this. ${ }^{15}$

11 On the Moriah tradition in Jewish literature of late antiquity, see Grypeou and Spurling 201 3: 50-4.

12 Tannas were rabbinic sages of the first and second centuries.

13 For a recent, balanced review of the scholarly discourse surrounding the date of $P R E$, see Adelman 2009: 35-42.

14 Expanding on Gen. 3: 19. Because Gen. 3: I9 has Adam returning to the ground out of which he was taken, he 'returns' to the place where he was formed ( $P R E$ I 2$)$.

15 On this, Gafni rightly notes that $P R E$ 'frequently incorporates conflicting traditions' 


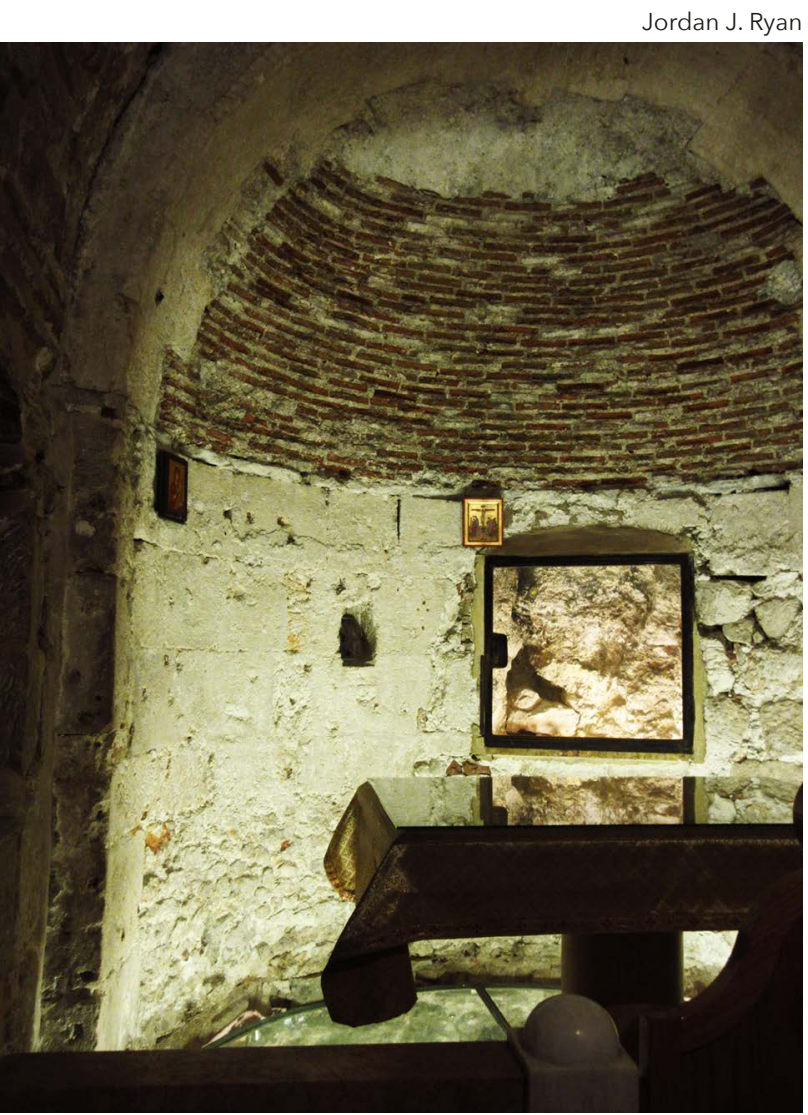

A portion of the traditional rock of Golgotha, visible in the Chapel of Adam, which is within the modern Church of the Holy Sepulchre. The Chapel of Adam is located directly under the place where the crucifixion of Jesus is commemorated. The original Chapel of Adam dates to the time of Modestus, in the seventh century CE.

Naturally, this implies an awareness of both traditions, which fits with the relatively late date of the text's compilation. Although it is frequently cited in discussions concerning the traditions of Adam's burial in relation to the fourth century, it is best understood as an important later reception of the Machpelah

(2019: 37-8, n. 38). Similarly, LipatovChicherin observes that $P R E$ makes no attempt to resolve the apparent contradiction (201 9: I 58). However, $P R E$ does make some attempt to resolve the contradiction, but it does so in a most implausible manner: by relocating the Cave of Machpelah to Mount Moriah. and Moriah traditions. Moreover, PRE 20.9 depicts Adam expressing a fear that his bones will be taken and used for the purposes of idolatry. As Adiel Kadari has recently argued (2016: 99), this probably reflects a familiarity with the Christian practice of the veneration of relics, and expresses Adam's awareness of his own non-divinity. Thus, Kadari suggests reading the story of Adam's burial in PRE against the Christian narrative of Jesus's death, burial, and resurrection, and thus contending with that narrative's assertion of the divinity of Jesus. This reading comes into even sharper relief when we consider the location of the site of Adam's burial at Golgotha in Christian tradition, and the incorporation of Golgotha into the monumental Church of the Holy Sepulchre. Thus, there may be a sense in which we can see $P R E 20$ at the intersection of the Machpelah, Moriah, and Golgotha traditions. Although I must admit that this is speculative, it is worth suggesting that the narrative of Adam's burial in PRE 20 might have been a particularly poignant engagement of the Christian tradition of the burial of Adam at Golgotha after the Chapel of Adam had been incorporated into the architecture of the Church of the Holy Sepulchre. Thus, it could have potentially addressed and engaged the Christian Adamic cult site that had emerged in Jerusalem at the time of Modestus in the seventh century. ${ }^{16}$

16 On Modestus and the Chapel of Adam, see the discussion of the architecture of the Church of the Holy Sepulchre below. This does not mean that I am suggesting that $P R E$ 20 necessarily dates to the time of Modestus. 
The burial of Adam

\section{in the Life of Adam and Eve texts}

As we shall see, the tradition of Adam's burial at Mount Moriah is sometimes thought to have an early, Second Temple period precedent in the Life of Adam and Eve. However, for reasons that will become clear below, attempts to find a Second Temple precedent, or indeed a precedent clearly dating prior to Origen, for the tradition of Adam's burial at Mount Moriah are problematic. The Life of Adam and Eve texts naturally provide a promising avenue for investigation, since they depict the death and burial of Adam. It is essential to recognise that the Life of Adam and Eve is extant in two forms: the Greek Life of Adam and Eve (GLAE) 17 and the Latin Life of Adam and Eve (Vita Adae et Evae, abbr. Vita). Both the Latin and Greek versions of the Life of Adam and Eve texts narrate specific episodes in the lives of Adam and Eve after their expulsion from Paradise, including their deaths. As we shall see, there is some debate in scholarship concerning their dates and origins. There are substantial textual differences between the Greek and Latin versions. Although the textual traditions are complex, the shorter Greek Life of Adam and Eve is regarded as the oldest extant version..$^{18}$ As printed in the commonly used edition of the Pseudepigrapha (Johnson I983), it appears as though these texts evince an early instantiation of the Mount Moriah burial tradition. However, the matter is severely complicated by text-critical issues and problems that occur when the $G L A E$ and $V i t a$ are inappropriately conflated.

According to the traditions preserved in GLAE, Adam's body was brought to Paradise

17 Also called the 'Apocalypse of Moses'.

18 See de Jonge and Tromp 1997: 30-44; de Jonge 2000: 239-49. For the critical text, see Tromp 2005. after his death (38:4). Abel's body was also brought (40:3-4) to the same place, and both Adam and Abel were "buried according to the command of God in the regions of Paradise

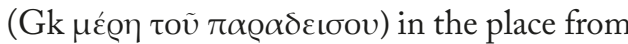
which God had found the dust'. ${ }^{19}$ This data provides us with yet another Jewish tradition about the location of Adam's burial, as GLAE situates Adam's burial place in the 'regions' of Eden, the very place where Adam was first created. This tradition probably stems from or at least alludes to the statement in Genesis 3:19 in which God tells Adam that he will 'return to the ground; for out of it you were taken; you are dust, and to dust you shall return'. As we discuss below, this tradition of Adam's burial in Paradise is paralleled in Jubilees 4:29.

Some scholars identify the place where Adam is buried in the Life of Adam and Eve with the site of the Jerusalem Temple (Johnson I983: 254, 270 n. 3; cf. Dow 2008: I $37-8)$. It is important to recognise that the ideas that Adam was buried where he was created and in (what would become) Jerusalem at Mount Moriah are not necessarily mutually exclusive, since Jerusalem could be identified as the place where Adam was created (as seen in PRE above), or the site of Paradise. M. D. Johnson notes several places in the GLAE and the Latin Life of Adam and Eve (Vita) which mention a place with an oratory (GLAE 5:3; Vita 30:2) or an altar (GLAE 33:4). He identifies this place with that where Adam was created and buried (GLAE 40:6), and refers to rabbinic sources that locate Adam's oratory on Mount Moriah (Midrash Psalms 92:6; Pesiqta Rabbati 43:2; PRE 23, 3I). Of particular note is Adam's instructions for where he should be buried as narrated in the Latin recension:

19 Translation from Johnson I983: 249-95. 
'if I should die, bury me against the East in the great dwelling place of God' (Vita 45:2). Combining this data, Johnson concludes 'There can be little doubt that the same site is intended in all such references and that the location is to be understood as the place of the Jerusalem Temple, where rabbinic sources fix the location of Adam's oratory' (Johnson I983: 254).

The argument for identifying the place of Adam's burial with Mount Moriah in the $G L A E$ requires further critical investigation. There are a few issues to address. The Latin version of the Life of Adam and Eve locates Adam's burial place on Mount Moriah, so long as we understand 'the great dwelling place of God' to be the place of the Jerusalem Temple. However, text-critical scholarship on the Life of Adam and Eve has shown that the Latin version is a late recension of the text, the result of extensive editorial activities. ${ }^{20}$ In fact, while the Greek text probably represents the earliest stages of the text, the Latin version represents the latest stage of development (de Jonge and Tromp I 997: 77; de Jonge 2003: 230; Menk and Meiser i 998 : 755-69). Moreover, some manuscripts disagree with the location, having Adam instead ask to be buried 'towards open country' (in agrum) or 'on land' (in agro) (see Johnson I983: 286 n. 45).

The date of the GLAE is difficult to determine. ${ }^{21}$ The state of the question in current scholarship is summed up by Marinus de Jonge and Johannes Tromp, who have suggested a wide range between the second and sixth centuries $\mathrm{CE},{ }^{22}$ although they prefer a

20 See de Jonge and Tromp I997: 37-40; Tromp 2002: 28-4I.

21 For a review of various proposed dates for the GLAE, see the helpful review in Nir 2004: 20-45 (45 n. 90).

22 See de Jonge and Tromp I997: 75-7. date between the second and fourth centuries (de Jonge and Tromp I997: 77). Furthermore, Tromp and de Jonge prefer to view the GLAE as a Christian composition, though one that incorporates Jewish traditions (de Jonge and Tromp 1997: 68-75). This hypothesis of the GLAE as a Christian composition has been further developed in more recent scholarship by Rivka Nir (2004), on the basis of the use of incense and aromatic fragrances in the narrative, and more recently, by Antti Laato (2018), who has argued that, although there are elements of the funeral rites depicted in $G L A E$ that can fit well in either a Jewish or a Christian setting, 'the final story must have been mediated by a Christian author(s)' and that the description of the funeral rites in GLAE 'contains traces of anti-Gnostic argumentation' (p. 68). Anne Marie Sweet has argued for a date no earlier than the second century CE (I992: 26). Johnson prefers a date towards the end of the first century CE ( 1983 : $25^{2}$ ), which is quite close to the earlier end of de Jonge and Tromp's range. By contrast, Nir has argued for a date closer to the later end of the range that Tromp and de Jonge propose, placing the GLAE in the fourth to fifth centuries CE (Nir 2004: 45). ${ }^{23}$ Thus, even if we date the GLAE to the earlier end of the proposed spectrum in the second century $\mathrm{CE}$, if the Latin version is the latest stage of the development of the text and dated substantially later, it is still extremely questionable as to whether Vita 45:2 reflects a Jewish tradition that would have been current when Origen wrote his Commentary on Matthew in the mid-third century CE. ${ }^{24}$ It is not impos-

Cf. discussion in Zemler-Cizewski 2004: $67 \mathrm{I}-7(674-5)$.

23 See, however, the counter-argument of Smit 2004: 369-75.

24 On the date of Origen's Commentary on Matthew, see Hanson 2004: I 6-I7; Hanson places it in $246 \mathrm{CE}$. 
sible that late texts can transmit earlier traditions, but no attestation of the Mount Moriah burial tradition can be clearly or indisputably placed prior to or contemporary with Origen. This leads to the conclusion that it is not likely to have been known to him. At the very least, we cannot be certain that the Mount Moriah burial tradition antedates Origen. Moreover, it is certainly possible that multiple competing traditions can co-exist, as shown by the existence of both the Moriah and Machpelah Adamic burial traditions in rabbinic literature. Even if the Moriah or Machpelah traditions were circulating in the third century CE, the co-existence of a Jewish tradition locating Adam's burial at Golgotha cannot be ruled out.

Moreover, there are significant problems with the passages in the GLAE that some have argued present Temple imagery in connection with the place in which Adam was created and buried. The key passages are $5: 3$, which mentions a 'house into which he [Adam] used to enter to pray to God', and 33:4, which mentions an altar. The narrative involving this altar is difficult to interpret, and may describe an altar located at the place where the events of chapter 33 take place, or a visionary altar that Eve sees upon the death of Adam. The mention of the 'prayer house' in $5: 3$ is a late addition to the text and was not included in the main text of the critical edition of the GLAE (Tromp 20 I6: 1 26-7).25 It is not found in the earliest manuscripts. Given the difficulty of dating the original composition of the GLAE with precision to Origen's time, it is unlikely that this late addition can be considered a witness to a tradition that would have been current in or prior to

25 De Jonge and Tromp note the point of contact between this mention of the 'prayer house' and the Cave of Treasures tradition (1997:33, 86). the third century CE. The altar mentioned in 33:4 is located at the place where Adam dies, but this is not where he is buried. The primordial humans are expelled from Paradise in chapters 28-9, and we are told in 29:6 that Adam 'went out of Paradise'. Then, in 38:3-4, the text describes the angels taking Adam's body from where it lay into Paradise. Thus, within the narrative of the GLAE, the altar mentioned by Eve in 33:4 is not located at the place where Adam is buried, but at the place where he died. We are left to conclude that GLAE located Adam's burial in the regions of Paradise.

The account of Adam's burial in GLAE is paralleled in a text that is more securely dated to the Second Temple period: the book of Jubilees. Jubilees $4: 29$, like the Life of Adam and Eve texts, narrates Adam's death. According to the author, 'All his children buried him in the land where he had been created'. 26 Much like the burial tradition in GLAE, this tradition seems to be rooted in an inference based on Genesis 3:19 (see also Jubilees 3:25) (cf. VanderKam 2018: 265). There is no indication here in Jubilees that the land where Adam was created was Jerusalem. However, we must also note that Jubilees appears to locate Adam's place of creation as somewhere other than Eden. This is because Adam is created before the Garden, and lived in the place where he was created for forty days before being moved into the Garden (Jubilees 3:9) (see VanderKam 20r 8: 2I5). All that we can conclude from this is that, according to Jubilees, Adam was buried where he was created (following Gen. 3:19), but the location of his creation is unspecified. Notably, it is unlikely that Adam's place of creation was the site of the sanctuary, since as VanderKam notes, Jubilees appears to

26 Translation from VanderKam 2018. 
be concerned to show that Adam and Eve remained outside the Garden after their creation, because the Garden is depicted and understood as a sanctuary in the context of Jubilees (VanderKam 201 8: 215).

To summarise, the earliest datable tradition in Jubilees has Adam buried where he is created, but the location of his creation is unknown, though it was explicitly not a sanctuary. The critical text of GLAE, that is, the earliest stratum of the Life of Adam and Eve texts, situates Adam's burial in the regions of Paradise. Later additions to the Life of Adam and Eve tradition do, however, appear to identity that site with the site of a Temple, and thus possibly Mount Moriah. The Mount Moriah tradition is generally difficult to date, but is most likely to be relatively late. The Machpelah tradition has a more certain date, since it is attested by Jerome towards the end of the fourth century CE.

Symeon Logothete (c. Ioth century $\mathrm{CE})$ cites a passage in the writings of Julius Africanus (2nd to 3 rd centuries CE) which locates Adam's tomb generally in 'the land of Jerusalem', and associates it with a 'Hebrew' tradition $^{27}$ (see Lipatov-Chicherin 2019: I $5 \mathrm{I}-78$ ): 'It is said that Adam was the first to be buried in the ground, from which he had been taken. And his tomb was in the ground of Jerusalem, according to what is reported in a Hebrew tradition.' 28 The tradition is no more specific about the location of the tomb than 'the ground of Jerusalem'. If the tradition's attribution to Julius Africanus is authentic, it would be the earliest known instantiation of the location of Adam's burial specifically in Jerusalem. As other scholars have noted, there is probably a connection

27 For the source and accompanying notes about some of the complexities surrounding it, see Wallraff 2007: 42-3, esp. n. I.

28 Translation from Wallraff 2007: 43 n. I. between the tradition cited in the fragment of Julius Africanus (as cited by Symeon Logothete) and the narrative of Adam's burial in Jubilees, since Jubilees 4:29 also narrates Adam's burial in the ground where he was created (Lipatov-Chicherin 2019: I56; Wallraff 2007: 43nI). Moreover, the idea that Adam was the first to be buried, implying that Abel was buried after Adam despite having died first, also coheres with the narrative of Jubilees (4:29).

The relationship between the Julius Africanus fragment concerning the burial of Adam and Jubilees 4:29 may thus best be understood as one of reception, though we cannot know if it is a direct reception of Jubilees 4:29 itself or of some shared tradition. Therefore, it is both plausible and convincing to suggest that the 'Hebrew' tradition that the fragment mentions may be the same one known from Jubilees, or perhaps Jubilees itself. However, we must recall that Jubilees does not specifically locate Adam's death in Jerusalem, and that what we see in the Julius Africanus fragment thus reflects a development in the tradition.

Nikolai Lipatov-Chicherin has reasonably suggested that, since 'Hebrew' is an ethnic rather than a religious designation and not necessarily interchangeable with 'Jewish', that the 'Hebrews' in question might be 'Hebrew Christians' (Lipatov-Chicherin 2019: I58). $\mathrm{He}$ also observes that Basil of Caesarea identifies this tradition as having been preserved in the Church (Commentary on Isaiah 5.I4 I), indicating a Christian genesis. When combined with Origen's identification of the 'Hebrew' origin of the tradition, this evidence supports the hypothesis of a JewishChristian (or 'Hebrew Christian') genesis for the tradition of Adam's burial at Golgotha (Lipatov-Chicherin 2019: I58). As a result, the possibility that the Julius Africanus fragment may have Golgotha specifically in mind 
cannot be ruled out. That said, the possibility that no specific place in Jerusalem was in view in the version of the tradition of Adam's burial related in the Julius Africanus fragment also cannot be ruled out. However, while it is tempting to view this fragment as an early attestation of the tradition of Adam's burial on the Temple Mount, we must remember that (assuming that this fragment's attribution to Julius Africanus is authentic), the evidence for the Jewish tradition of the burial of Adam on the Temple Mount is late, and its circulation in this period is unattested.

\section{Analysing the various traditions}

It is difficult to parse the relationship between the various strands of Jewish traditions concerning the location of Adam's burial and the Christian tradition of Adam's burial at Golgotha. The relative chronology of the development of the traditions is also complex. Here is a summary of what we have found. The earliest datable tradition is the one found in Jubilees 4:29, in which Adam is buried where the ground was taken for him to be formed. However, although it would be natural to assume that Eden was where this occurred, the narrative of Jubilees specifically has Adam formed outside Eden (3:9), where he lived for forty days before entering the garden. Thus, the location of Adam's burial and creation is left unspecified. Wherever the author of Jubilees imagined Adam's burial to take place, it was specifically not a sanctuary, since the theological purpose of locating Adam outside Eden for forty days is tied to the notion that Eden was a sanctuary.

The tradition that Adam was buried in Jerusalem may well first appear in a Christian source, as it is reported in a fragment attributed to Julius Africanus. If the attribution is correct (a matter that cannot be certain given the late date of the source of the fragment),
Julius Africanus may also be the earliest witness to a tradition of specifically locating Adam's burial in a known location. However, the location is simply Jerusalem. No specific site within the city is identified. Around the same time as Julius Africanus, Origen identified the site of Adam's burial as Golgotha. Both Origen and Julius Africanus claimed a 'Hebrew' origin for the tradition(s) that they reported. However, what that claim actually means, and the question of its authenticity are complicated matters and not immediately clear.

The GLAE (as attested by the critical edition of the Greek text) locates Adam's burial within Paradise. However, this text is particularly difficult to date. Although the most commonly used English edition of the Life of Adam and Eve texts dates it to the first century CE (Johnson I 983: 249), subsequent scholarship has tended to date it much later, some time between the second and sixth centuries CE. Furthermore, serious questions have been raised about whether the text is better understood as a Jewish text or as a Christian text making use of Jewish traditions and elements, with some weighty arguments now perhaps tipping the balance towards the latter (Tromp I997; Nir 2004; Laato 2018). Subsequent versions of the Life of Adam and Eve, both in the Greek textual tradition and in the Latin version ( Vita), contain elements that can be interpreted as though they presuppose a temple context for Adam's burial, and thus perhaps a Mount Moriah setting. However, these additions almost certainly postdate the Golgotha tradition. Moreover, it is clear that they are modifications of an earlier tradition of Adam's burial in Paradise. It is important to remember that, if the GLAE is a Christian composition, it might well utilise earlier Jewish traditions. Nevertheless, without evidence, it is entirely speculative to date any such hypothetical pre-existing traditions 
prior to the initial authorship of the GLAE.

The tradition of Adam's burial at Kiryat Arba (Hebron) is well attested in a number of late-antique rabbinic sources (b. Erub. 53 a; Genesis Rabbab 58:4, 9; PRE 20.9). These texts and the traditions that they witness are notoriously difficult to date with precision. However, there is a datable Christian reception of the Kiryat Arba tradition in Jerome, who appears to genuinely report a Jewish tradition that must have already been in circulation by the late fourth century CE. Other relatively late rabbinic sources locate the burial of Adam on Mount Moriah (Midrash Psalms 92:6; Pesiqta Rabbati 43:2; PRE 23, 3I). Attempts to support an early date for the Mount Moriah tradition are problematic, since no reliably datable evidence exists, and the citations from GLAE and Vita of examples of Temple imagery are complicated by text critical and tradition historical issues. While it is certainly possible that these late texts contain early traditions, a lack of evidence renders attempts to project traditions attested only in late sources speculative. Thus, of the traditions of Adam's burial site that we have discussed, the Mount Moriah tradition may well have been the latest to appear.

What is the relationship, if any, between these traditions? It is difficult to imagine that all of these traditions were wholly independent of one another, and that Jews and Christians who were interested in the question of Adam's burial were not aware of the various other traditions that circulated. In fact, the evidence actually seems to indicate that there was awareness of the multiplicity of traditions about the location of Adam's tomb: Jerome knows both the Golgotha and the Kiryat Arba traditions, the later editors of the Life of Adam and Eve texts appear to know the tradition of Adam's Temple burial while using or editing a text that locates Adam's tomb in Paradise, $P R E$ clearly witnesses both the Kiryat Arba and the Mount Moriah traditions, and Julius Africanus, for whom Jerusalem was the place of Adam's burial, knew the tradition attested in Jubilees that Adam was buried where he was created. I suggest that a nuanced perspective on the relationship of the traditions of the location of Adam's burial should recognise the phenomenon of the development of traditions, sometimes including the combination of multiple traditions, as well as the phenomenon of the competition of traditions.

The suggestion offered by the various scholars discussed above that there may be polemic involved in the development of competing traditions is insightful. Certainly, if we understand that there were different traditions in competition with one another, as we see clearly in the writings of Jerome, for example, who knows both the Golgotha and the Kiryat Arba traditions, these traditions could have been born from polemic, or could have been employed for polemical purposes. For example, given the apparent relatively late dates of its attestation, it is at least plausible that the Mount Moriah tradition arose in Jewish circles in late antiquity in response to the Christian use of a tradition of Adamic burial at Golgotha, which had become well known in Palestine by the fourth century CE, and to the incorporation of Golgotha into the Church of the Holy Sepulchre. These sites also competed in other ways: Mount Moriah was, after all, seen as the centre of the world in Jewish tradition, ${ }^{29}$ while for Christians,

29 Note, for example, the notion of Jerusalem as the centre of the world in Second Temple literature (Jubilees 8: 9 , in which Mount Zion is the centre of the world; Philo, Legatio ad Gaium 294), as well as the later Rabbinic concept of the Temple specifically as the centre of the world (for example, in the Tanhuma to Leviticus, Qedoshim 10). 


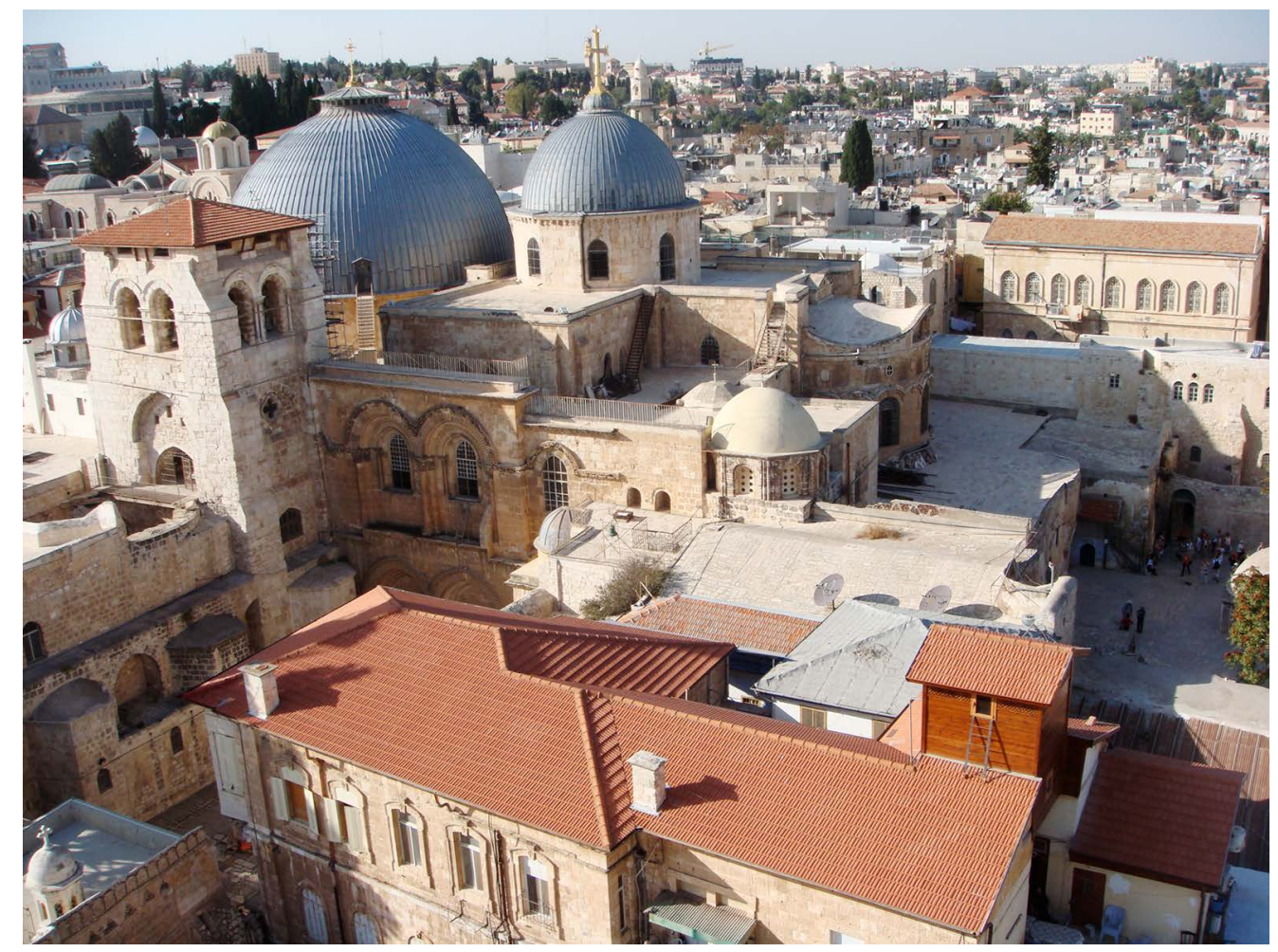

The modern Church of the Holy Sepulchre in Jerusalem. Photo courtesy of Anders Runesson.

this was Golgotha (see Alexander I 997). ${ }^{30}$

That said, we need not understand the relationship of the Christian traditions of Adam's burial to the Jewish traditions of Adam's burial solely in terms of polemic or response. In some cases, the relationship is better characterised as reception and development, as with Julius Africanus's use of the Jubilees tradition that Adam was buried where he was created, with the development that the place in question was Jerusalem, and the subsequent development of Julius Africanus's tradition witnessed by Origen, locating the tomb specifically at Golgotha. The Kiryat Arba tradition may well have had polemical value, as Gafni (2019: 42) has argued, as an insistence on a strongly and thoroughly Jewish site

30 For example, Cyril of Jerusalem, Catecheses, I 3.28 . for the burial of the protoplasts as opposed to Golgotha. This would have had particular currency in the fourth century, when the traditional site of Golgotha had been incorporated into the new Christian temple in Jerusalem: the Church of the Holy Sepulchre. It is possible that the Kiryat Arba tradition could have developed on its own independently of the emergence of the Golgotha tradition. Nevertheless, its appearance in the late fourth century certainly lends some credibility to the possibility that its emergence is not unrelated to the construction of the Church of the Holy Sepulchre and the popular spread of the Golgotha burial tradition. Whatever the case, the Kiryat Arba and Golgotha traditions should at least be viewed as competing traditions. Jerome certainly saw the two as being in competition (Commentary on Matthew 27:33), a fact that is important, 
given his apparent dislike of the Golgotha tradition (see discussion below).

\section{The reception of the Adamic Golgotha tradition in fourth-century Christian exegesis}

Golgotha looms so large in early Christian imagination and memory that we cannot hope to cover every single reference to it in any depth in an article of this length. As such, this discussion will focus particularly on sources with Palestinian provenance or connections. This will give us a more manageable dataset, and allow us to at least draw some broader inferences about Golgotha in the Palestinian tradition. It will also allow us to consider and examine the interaction and relationship between Christian and Jewish streams of traditions specifically within Palestine.

The Adamic Golgotha tradition first witnessed by Origen is received and further elaborated in fourth-century Christian writings. That interest was probably stimulated by the construction of the Church of the Holy Sepulchre in the second decade of the fourth century, and by the visible prominence of the rock of Golgotha in the inner courtyard of the Holy Sepulchre compound. As the continued presence and use of the Chapel of Adam in the modern Church of the Holy Sepulchre witnesses, this tradition has become a fixed dimension of the commemoration of Jesus at this particular place. ${ }^{31} \mathrm{~A}$ review of some of the key examples from the fourth century of this tradition will help us to better understand the reception, development, and use of the tradition of Adam's burial at Golgotha in the age of Constantine and beyond.

31 On the reception of this tradition in the Byzantine period and beyond, see Bagatti 1977: 5-32; cf. Mancini I 965: 277-82.
Epiphanius (c.310/20-403) mentions the Adamic Golgotha tradition in his polemical discussion of Tatian's belief that Adam cannot be saved. ${ }^{32}$ The course of this polemic (Panarion 46) leads Epiphanius to raise the Adamic Golgotha tradition in the theological context of his refutation of Tatian:

And so we must be surprised at someone (like Tatian) who knows - as I too have found in the literature - that our Lord Jesus Christ was crucified on Golgotha, nowhere else than where Adam's body lay buried. For after leaving Paradise, living opposite it for a long time and growing old, Adam later came and died in this place, I mean Jerusalem, and was buried there, on the site of Golgotha. This is probably the way the place, which means 'Place of a Skull', got its name, since the contour of the site bears no resemblance to a skull.... Why the name 'Of the Skull' then, unless because the skull of the first-formed man had been found there and his remains were laid to rest there, and so it had been named 'Of the Skull'? By being crucified above them our Lord Jesus Christ mystically showed our salvation, through the water and blood that flowed from him through his pierced side - at the beginning of the lump beginning to sprinkle our forefather's remains, to show us too the sprinkling of his blood for the cleansing of our defilement and that of any repentant soul; and to show, as an example of the leavening and cleansing of the filth our sins have left, the water which was poured out on the one who lay buried beneath him, for his hope

32 Concerning Tatian on the salvation of Adam, see Peterson 2008: I 25-58 (I $42-$ 52). Tatian was a second-century Christian who was the author of the Diatessaron, a harmony of the four canonical Gospels. 
and the hope of us his descendants. Thus the prophecy, 'Awake thou that sleepest and arise from the dead, and Christ shall give thee light', was fulfilled here. (Panarion $46.5 \cdot I-9)^{33}$

In Epiphanius's estimation, the name 'Golgotha' cannot be explained by reference to the physical features of the place that was identified as Golgotha in the fourth century, and thus the name must refer to an actual skull (see Jacobs 20r6: r44). As mentioned above, this passage appears in the course of a refutation of Tatian's stance on the salvation of Adam. ${ }^{34}$ The potential soteriological significance of the imagery of water and blood flowing from the side of the crucified Christ (5.7; cf. John I 9:34; see also I John 5:6) at the very place where Adam lay buried is not lost on Epiphanius. Accordingly, he writes of the 'sprinkling' of the water and blood poured out from Christ on 'our forefather's remains' (5.8) as having 'mystically showed our salvation' (5.7). Moreover, the water 'poured out on the one who lay buried beneath' is 'an example of the leavening and cleansing of the filth our sins have left' (5.8). It is worth noting that

33 Translation from Williams 2009: 379-80.

34 Jacobs argues that Epiphanius's point here is 'the effect of the Bible as a site of antiquarian display', since 'it is less clear how this biblically inspired geographic detail supports his heresiological point (that Adam was saved)' (Jacobs 20I6: I44). I would agree that this passage does indeed highlight the effect of the Bible as a site of antiquarian display, but this does not exclude the heresiological/soteriological point that Epiphanius makes through the use of this tradition. As Grypeou and Spurling write concerning the theological dimension of the Adamic Golgotha tradition, 'Adam must be buried in the place where Jesus was crucified in order for him to receive direct salvation through Jesus' sacrifice' (2013: 73).
Epiphanius relies heavily upon the Johannine theological tradition of the New Testament in his interpretation and reception of Golgotha (John I 9:34; cf. I John 5:6), while also making reference to the Pauline tradition (Eph. 5:I 4; Pan. 5.9). This helps to develop the Adam-Christ typological interpretation of Golgotha in a new direction. Epiphanius, in whose day the rock of Golgotha was visible, granted literal theological significance as well as symbolic significance to the place of Golgotha as the site of the crucifixion as well as the place of the literal skull of Adam.

As a result of his interpretation of Golgotha as the place where Adam was buried and subsequently cleansed by the water and blood of Christ 'for his hope and the hope of us his descendants' (5.9), Epiphanius considers Golgotha to be the place where the 'prophecy' of Ephesians 5:I4 ('Awake thou that sleepest and arise from the dead, and Christ shall give thee light'35) was fulfilled. While Origen saw Golgotha's location as fitting for both the place of Adam's burial and Christ's crucifixion, its significance was mostly symbolic. For Epiphanius, by means of his reference to the Johannine water and blood tradition, the matter is more visceral. The water and blood shed from Christ's side were poured out on Adam's remains, exemplifying the redemptive effect of Christ's death for humanity and demonstrating, against Tatian, the salvation of Adam.

Epistle 46, written circa 386 cE by Jerome to Marcella in the name of his close associates in Bethlehem, Paula and Eustochium, mentions the Adamic Golgotha tradition in a form that is remarkably similar to that known by Epiphanius. It states,

Tradition has it that in this city, nay, more, on this very spot, Adam lived and died.

35 Translation from Williams 2009: 380. 
The place where our Lord was crucified is called Calvary, because the skull of the primitive man was buried there. So it came to pass that the second Adam, that is the blood of Christ, as it dropped from the cross, washed away the sins of the buried protoplast, the first Adam, and thus the words of the apostle were fulfilled: 'Awake, you that sleep, and arise from the dead, and Christ shall give you light.' (Jerome, Epistle 46.3) 36

Here, Golgotha again serves as a geographical point of contact between the memory of Christ and the biblical conception of Adam, as the place where Christ was crucified and where Adam was buried. The similarities to Epiphanius's reception of Golgotha are notable. The notion of the blood of Christ falling on the remains of Adam and cleansing his sins and the fulfilment citation of Ephesians 5:1 4 are both present here. However, Jerome writes in his Commentary on Ephesians,

I know that I have heard someone preaching about this passage in church. As a theatrical marvel he presented a model never before seen by the people so that it was pleasing. He said of this testimony, that it is said that Adam was buried at Calvary where the Lord was crucified. The place was called Calvary [i.e. skull], therefore, because the head of the ancient man was buried there. At the time when the Lord was crucified, therefore, he was hanging over Adam's grave and this prophecy was fulfilled which says, 'Awake,' Adam, 'who are asleep and arise from the dead,' and not

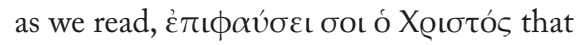
is, 'Christ will rise like the sun on you,' but

36 Translation from Fremantle r 892: 6r; on the date, see p. 60.

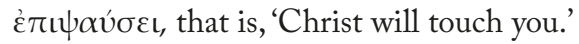
That was because, of course, by the touch of his blood and hanging body Adam would be made alive and would arise. That type was also truly fulfilled at the time the dead Elisha awakened the dead. Whether these things are true or not I leave to the reader's decision. They were certainly pleasing at the time they were spoken among the people who received them with applause and by stamping their feet. I mention one thing which I know: that understanding does not fit with the interpretation and coherence of this passage. (Jerome, Commentary on Ephesians 5:I 4$)^{37}$

This work is dated to 386-8 (Heine 2002: 7). 38 Thus, if there was a shift in Jerome's thinking on the Adamic Golgotha tradition and its interpretation here, it must have come about in a relatively short period of time. Lipatov-Chicherin has argued that the unnamed preacher was John of Jerusalem or one of his followers. Thus, the quick shift in Jerome's attitude can be attributed to his falling out with John of Jerusalem (LipatovChicherin 2019: I73-4). This offers one reasonable explanation for the dissonance between his Commentary on Ephesians and Epistle 46. However, another possibility is that Epistle 46 may represent the views of Paula and Eustochium on Golgotha, in whose name the letter is written, rather than those of Jerome (cf. Laato 20I4: I748). In my opinion, the role of Paula and Eustochium as authors of Epistle 46 provides a reasonable and parsimonious solution to

37 Translation from Heine 2002: 224.

38 For specific discussions of the date of this epistle, see Nautin I 979: 5-I 2; Kelly I 975: I45. Jerome himself comments on the composition of the commentary in Jerome's Commentary on Ephesians, Preface, I.53940 (Heine 2002: 76-7). 
the problem at hand. Paula and Eustochium could simply have had a different opinion on the Golgotha tradition from Jerome. It is preferable to view the instantiation of the Golgotha tradition in Epistle 46 as coming from Paula and Eustochium, as opposed to Jerome's own view, expressed in his commentary on Ephesians 5:I 4.

Jerome states that he heard the Adamic Golgotha burial tradition and its connection to Ephesians 5:14 in a sermon in a church setting. This is significant in and of itself for the study of the transmission and reception of extra-biblical traditions in early Christianity. Common church gatherings and sermons could be settings for the popular oral transmission of traditions, both antiquarian and exegetical. Several elements in common with Epiphanius' reception and interpretation of Golgotha/Calvary are constant here: the notion that the name of Golgotha is related to its status as the burial place of Adam, the belief that Christ's blood was poured out on Adam's remains to salvific ends, and that this fulfilled the tradition cited in Ephesians 5:14. Given these consistencies, it is reasonable to suggest that these common elements were a part of the form in which the tradition typically circulated in Palestine by the final quarter of the fourth century CE.

The tradition of remembering the event of the crucifixion at Golgotha in light of Adamic Christology had made its way into the Syriac tradition by the mid-fourth century, as seen in Ephrem the Syrian's Hymn on Virginity I6. Io: 'Very sad was the Tree of Life that saw Adam hidden from him. Into the virgin earth he sank and was buried, but he arose and shone forth from Golgotha.'39 The Commentary on Isaiah attributed to Basil of Caesarea (in Cappadocia) also contains a number of extra-biblical traditions

39 Translation from McVey I989: 332. concerning Adam, including some discussion about the Place of the Skull (Golgotha). ${ }^{40}$ Even further afield, other references to Adam's burial at Golgotha dated to the fourth century are found in the works of John Chrysostom (Homiliae in Joannem 85 on John I9: 1 6-r 8), and Ambrose (Expositio Evangelii secundum Lucam Io. I I4). Notably, Ambrose identifies 'the Hebrews' as the source of the Golgotha burial tradition, in agreement with Origen. The mere fact that this tradition is cited at all by these influential Christian thinkers based outside of Palestine speaks to how widespread it had become before the close of the fourth century. The notion that it stemmed from 'Hebrews' again highlights the perceived connection that this tradition has to Jewish sources. Whether or not the tradition actually stemmed from a 'Hebrew' source (i.e., from ethnic Jews or Jewish-Christians) is beyond the point here. The tradition was received, perhaps as a result of Origen's instantiation of it, as having a 'Hebrew' source. This underscores the perception of the antiquity of the tradition of Adam's burial at Golgotha, as well as the Christian claim to the legacy of Adamic traditions.

It is striking that Golgotha is so strongly remembered in the early Christian tradition in light of Paul, despite the fact that Golgotha is never mentioned in the Pauline texts of the New Testament. There are two ways in which the memory of Golgotha has been thoroughly coloured by Paul in the early Christian tradition: first, through direct references to Pauline literature in Christian reception and interpretation of Golgotha, ${ }^{41}$ and

40 On the authorship of the Commentary on Isaiah by Basil, see Lipatov-Chicerin I993: $42-8$.

41 By 'Pauline', I mean to refer not only to the undisputed epistles, but the New Testament Pauline corpus in general, which were 
second, through the Christ-Adam typology in Pauline mode that infuses popular early Christian interpretation of Golgotha following Origen.

The tradition of tying Adam to the memory of Golgotha is clearly inspired and influenced by Paul's Adam-Christ typology (I Cor. I 5:2 I-2, 45-9; Rom. 5:I2-2I). By the mid-fourth century, Ephesians 5:I 4 had entered into the collective memory of Golgotha. Despite its lack of mention of either Adam or Golgotha, both the nomenclature of the place and the Adam-Christ tradition came to be interpreted in light of it. This, in my opinion, represents an evolution of the collective memory of the site that gained in popularity in the second half the fourth century, well after the traditional rock of Golgotha had been visibly incorporated into the precincts of the Church of the Holy Sepulchre. Ephesians 5:14 is mentioned in connection with Golgotha by Pseudo-Athanasius, ${ }^{42}$ Epiphanius, Jerome, Paula and Eustochium, and by the unnamed preacher discussed by Jerome in his Commentary on Ephesians 5:14. The use of Ephesians 5:I 4 in connection with Golgotha is curious, given that it mentions neither Adam nor Golgotha. It does not even mention the crucifixion. The image is one of resurrection, and the 'sleeper' is identified as Adam, whose remains lie at Golgotha, and is redeemed by the blood of Christ who is crucified in the same place, allowing for the hope of Adam's resurrection. The memory of Jesus at Golgotha is thus coloured by the church's memory of Paul.

Although no architecture nor official liturgy connected the Holy Sepulchre complex

understood by the Church Fathers to be Pauline.

42 That is, the author of De passione et cruce Domini, which is attributed to Athanasius of Alexandria. to Adam in the fourth century, there is some evidence that indicates that visitors nevertheless made the connection for themselves. The Jerusalem Breviarius is a short pilgrimage guidebook to Jerusalem that postdates the fourth century in the two extant recensions (A and B) in which it has been preserved. However, when one compares the two recensions, it becomes clear that they are both later recensions of an earlier text. John Wilkinson has convincingly reconstructed that earlier version of the Breviarius by subtracting the unique material added by both manuscript traditions ( $\mathrm{A}$ and $\mathrm{B}$ ), leaving only the base text, which is shared in common by the two (Wilkinson 2002: 3-4, I I 7-2 I). Based on its content, the base text is best dated to the late fourth century.

This fourth-century version of the Breviarius describes the area of Golgotha as it existed within the Church of the Holy Sepulchre complex (Breviarius 2). According to the anonymous author, 'There Adam was formed. There the Lord was crucified'. ${ }^{43}$ This is a curious variation on the AdamChrist Golgotha tradition, since it identifies Golgotha as the place where Adam was formed, but does not mention Adam's burial at the same site, though it does explicitly draw a parallel between Adam's formation and Jesus's crucifixion on the same spot.

This text needs to be understood in light of the earlier tradition that Adam was buried where he was formed, first attested in Jubilees 4:29, which states that 'all of his [Adam's] children buried him in the land of his creation'. ${ }^{44}$ It also later appears in $G L A E$ 40:6, which explicitly states that Adam (and

43 Translation from Wilkinson 201 5: 93. All subsequent translations of the Jerusalem Breviarius are taken from this source unless otherwise stated.

44 Translation from Johnson I983: 63 . 
Abel along with him) was 'buried according to the command of God in the regions of

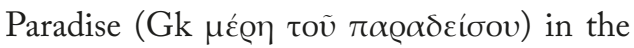
place from which God had found the dust' (see the discussion of this tradition above). If this was combined with the well-attested tradition already known in Christian circles by the third century that Adam was buried at Golgotha (see above), one would naturally come to the conclusion that Adam must also have been formed at the same place. This is one of the closest connections between Jewish and Christian Adam traditions in fourth-century Christian literature. It is thus very likely that the tradition that Adam was formed at the traditional site of Golgotha, located in the fourth century in the inner courtyard of the Church of the Holy Sepulchre, which is witnessed here by the Jerusalem Breviarius, is a Christian reception and redeployment of the earlier Jewish tradition about Adam being buried where he was created. In this case, the relationship between the traditions at play is one of reception, development, and combination.

\section{The Church of the Holy Sepulchre: Jewish Adam traditions and Christian supersessionism in architectural form 45}

The traditional site of Golgotha, along with the traditional site of Jesus's burial, were incorporated into the Church of the Holy Sepulchre during the reign of Constantine. Construction took place between 325 and 335 , coinciding with the dates of Constantine's

45 The presentation of the architecture here is derived from a combination of the key archaeological studies of Coüasnon I974; Patrich I993; Gibson and Taylor I994; Shalev-Hurvitz 201 5: 43-77; and Kelley 20I9. I refer to Shalev-Hurvitz 2015 and Kelley 2019 for the most recent overviews of the archaeological evidence and architecture. bicennalia and tricennalia. The church consisted of a large complex. Moving from east to west, a visitor would have entered from the Jerusalem cardo through a monumental entryway leading into an atrium. From the atrium, one would enter the Martyrion, an apsed basilica boasting a nave and four aisles, which was oriented from east to west. The apse featured twelve columns. Exiting the Martyrion on the west side via one of two gates just north and south of the apse, our visitor would come to a tri-porticoed inner courtyard. The Rock of Golgotha was displayed in the south-east corner of this courtyard. Beyond the courtyard was the Anastasis, which was half of a 24-sided polygonal, domed rotunda with small apses on the north, south, and west sides. Inside the Anastasis was a semi-circular interior wall which created an ambulatory space surrounding the Aedicule, a structure which was the focus of the entire complex. The Aedicule housed the remains of a rock-cut tomb, which was (and still is) the traditional site of Jesus's burial and subsequent resurrection. On the surface, the Church of the Holy Sepulchre presents testimony in architectural form to the crucifixion, burial, and subsequent resurrection of Jesus of Nazareth. By moving through the structure beginning from its monumental eastern entrance off the cardo on the eastern end, one's journey would come to its completion at the Aedicule. Much like Solomon's Temple, which progressed in increasing sanctity from the outer court through to the Holy of Holies, so too do the structures of the Holy Sepulchre progress in sanctity, terminating in the tomb chamber.

It is important to consider what is missing from the Church of the Holy Sepulchre. None of the official architecture or space in the church commemorated Adam or his burial in the fourth century. Architectural space devoted to Adam did not appear at 


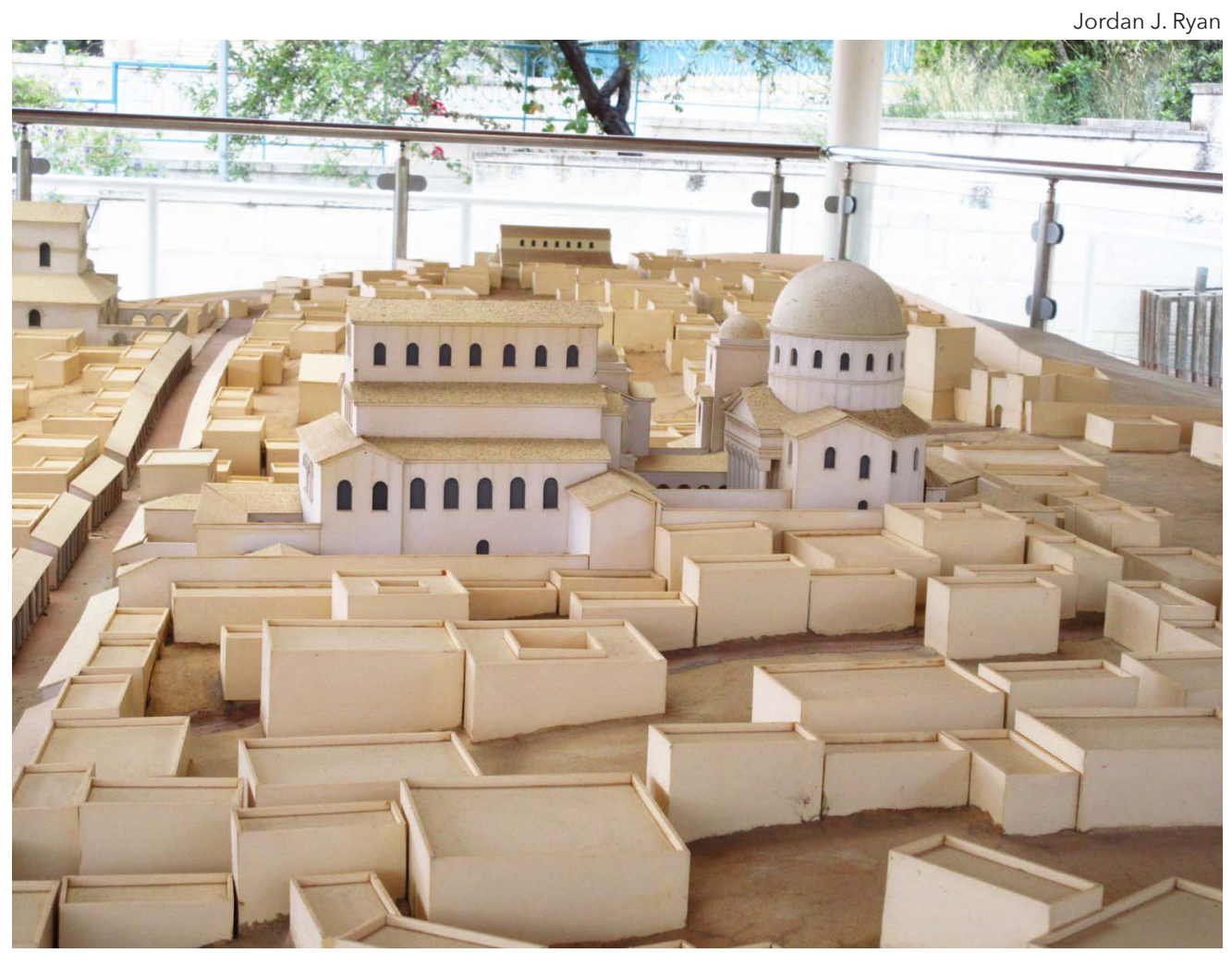

A model of the Constantinian Church of the Holy Sepulchre at St Peter in Gallicantu, Jerusalem. The model shows the two main structures, the Martyrion and the Anastasis, as they would have existed in antiquity.

the Holy Sepulchre complex until the time of Modestus, despite the popularity of the Adamic Golgotha tradition in the third and fourth centuries CE. As mentioned above, official Adamic commemorative space, in the form of the Chapel of Adam, probably first appeared at the time of Modestus in the seventh century CE. Thus, so far as the architecture is concerned, the Adamic tradition is a late addition to the narrative. However, the Adam Golgotha tradition saw a rapid increase in popularity in the fourth century, which is almost certainly due to the renewed interest in Golgotha resulting from the construction of the Church of the Holy Sepulchre. The preservation and further generation of Christological Adamic traditions connected to Golgotha were thus an unintended consequence of its construction, eventually resulting in the fixing of the tradition in the official memory of the site through the construction of the Chapel of Adam in late antiquity.

According to Eusebius, the 'New Jerusalem', by which he means the Church of the Holy Sepulchre, faced the Jerusalem of old, 'which after the murder of the Lord had been overthrown in utter devastation, and paid the penalty of its wicked inhabitants' (Life of Constantine 3.33). This antiJewish vitriol is an unfortunate instantiation of the reception of the New Testament passages which appear to place the blame for Jesus's death upon the Jewish inhabitants of Jerusalem, ${ }^{46}$ combined with Jesus's predic-

46 For example, esp. Matt. 27:25, but also Mark I 5:9-1 5; Matt. 27:20-3; Luke I3:2 I; 
tion of the destruction of the Temple (Mark I3:I-2; Matt. 24:I-2; Luke 2I:5-6). The implication was that the Church of the Holy Sepulchre was the successor to the Jewish Temple. The date of the dedication of the Church of the Holy Sepulchre was the very same as the biblical date of Solomon's dedication of the original Jerusalem Temple (I Kgs. 8 , esp.vv. I-2). ${ }^{47}$ The selection of this particular date intentionally presented the Church of the Holy Sepulchre as the successor to the Temple, and thus, the church as the heir to Jerusalem. The presentation of the Church of the Holy Sepulchre as the successor to the Temple was further bolstered by the fact that, as John Wilkinson has shown, it was built according to the plan of Ezekiel's vision of the heavenly temple (in Ezek. 40; Wilkinson 1993: 23-7 and 1999: 62-4). Thus, it represented the 'triumph' of Christianity over Judaism and the ideology of supersession in architectural form.

\section{Conclusion}

The name of Golgotha, translated but not explained in the canonical New Testament, attracted exegetical interest in early Christian literature. By at least the third century, Golgotha was associated in Christian memory with the burial place of Adam. This association was facilitated by the nomenclature of the place where the crucifixion took place. The Adamic Golgotha tradition was widely disseminated in the fourth century, probably invigorated by the construction of the Church of the Holy Sepulchre.

The relationship of the tradition of Adam's burial at Golgotha to Jewish traditions about Adam's final resting is a complicated matter.

John I 9:2 8b-40, 20:1 9. See also I Thess. 2:I4-I 5 .

47 As also noted by Finkelstein 201 8: 102.
We have discerned several different traditions about Adam's burial in both Jewish and Christian sources. As discussed above, the earliest extant tradition about Adam's tomb locates it at the place where Adam was created, in Jubilees 4:29. Although the specific location is not given by the author of Jubilees, we can discern that it was not Eden, nor was it a sanctuary, and thus not the Temple, and probably not Mount Moriah. This early tradition that Adam was buried where he was formed found later reception in sources as diverse as Julius Africanus, the GLAE, and the earliest recension of the Jerusalem Breviarius. Assuming that the citation fragment is authentic, the tradition that Adam was buried in Jerusalem, which is also where he was formed, is attested by Julius Africanus (second to third centuries CE). This tradition develops further, so that Origen conveys a tradition that locates Adam's burial specifically at Golgotha, indicating that the Golgotha tradition was in circulation by the third century at the latest. This tradition is popularised and further developed exegetically and theologically in the fourth century CE by various Christian authors and by the incorporation of the traditional site of Golgotha into the interior courtyard of the Church of the Holy Sepulchre. The tradition that Adam was buried in Paradise, which is where the dust was taken for Adam's formation, is attested in GLAE, a text that is increasingly understood as a Christian composition making use of Jewish traditions and elements. The dates of this text and of the Paradise burial tradition are difficult to discern; plausible dates stretch from the second to sixth centuries.

By the late fourth century, a Jewish tradition siting Adam's burial site at Hebron had emerged and was in circulation. Its first clear appearance postdates the construction of the Church of the Holy Sepulchre in the fourth 
century and the earliest witness to the AdamGolgotha tradition in the third century. Another Jewish tradition appears in later rabbinic literature, which locates Adam's burial at Mount Moriah. The exact chronological relationship of these two traditions that are witnessed in the texts to the Golgotha tradition or to the construction of the Church of the Holy Sepulchre is uncertain, since it is hypothetically possible that these traditions emerged long before the extant texts in which they first appear. However, we should recognise that these traditions were in competition with the Golgotha tradition, which was symbolically represented by the visible presence of the traditional site of Golgotha within the Constantinian Church of the Holy Sepulchre. Moreover, the first datable appearance of the Kiryat Arba (Hebron) tradition in the late fourth century, and its clear connection with Jewish heritage through Abraham and Sarah's burial place, does suggest that the Kiryat Arba tradition is likely to have functioned as a Jewish response or alternative to the Golgotha tradition and as a response to its Christological claims, including the Pauline Adamic Christology associated with Golgotha in third- and fourth-century Christian exegesis. Insisting on Adam's burial at the site of the Tomb of the Patriarchs would have laid a Jewish claim to the legacy of Adam (and thus, humanity) while simultaneously undermining the power of the symbolism of the Church of the Holy Sepulchre and the tradition of Adam's burial that was alleged to take place on the spot where it was built.

For Christians, passages from Pauline epistles, naturally including the Adam-typology passages in I Corinthians $\mathrm{I} 5: 2 \mathrm{I}-2$, 45-9; Romans 5:I 2-2 I, played an important role in the way that Jesus was remembered in connection with the tradition of Adam's burial at Golgotha. However, Ephesians 5:I4 was widely attached to the Adamic burial tradition at Golgotha, for reasons that are

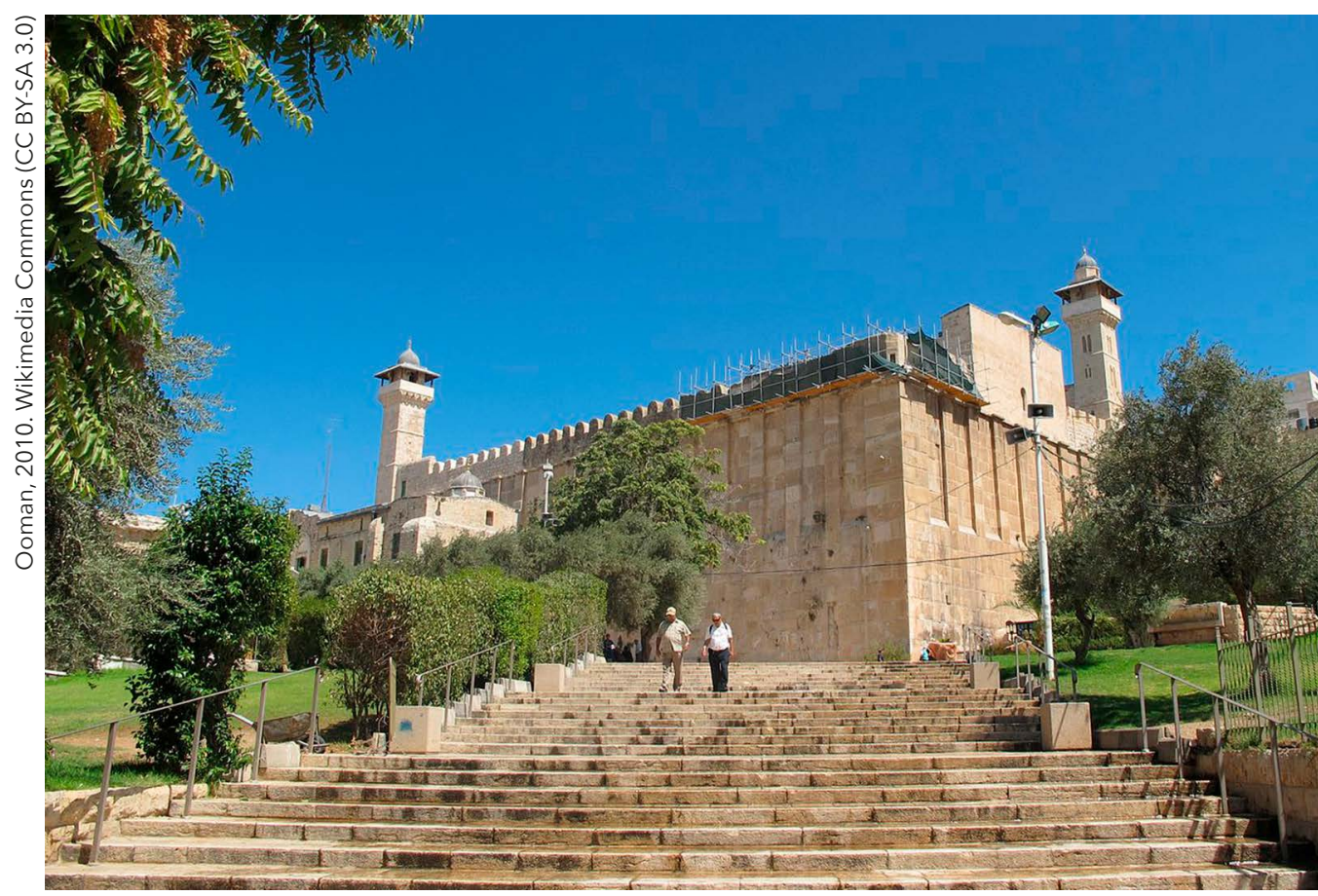

The Tomb of the Patriarchs at Hebron, Palestine. 
not immediately apparent. The association of Ephesians 5:14 with Golgotha is so strong that the evidence may suggest that this passage could have been utilised in the liturgical readings associated with Golgotha or with the Passion narrative. ${ }^{48}$ Egeria, a Christian woman and author who travelled to Palestine on pilgrimage in the late fourth century, mentions in her itnerarium (travel diary) that there were readings from the letters of the apostles that took place at the commemorative services at Golgotha (Itinerarium Egeriae 37.5 ), so this is certainly a possible explanation for what is otherwise an enigmatic exegetical tradition.

The architecture of the Church of the Holy Sepulchre represents an innovation in the reception and memory of Golgotha. Through its architecture, it communicates supersessionist concepts, presenting itself as the eschatological New Jerusalem, the new Temple, triumphing over Jewish Jerusalem and its ruined Temple. In the mind of Eusebius and countless other Christians who visited the site in antiquity, the juxtaposition of this 'New Jerusalem' over against the ruins of the Jewish Temple was an instantiation of the Christian anti-Jewish accusation of the Jewish people as (in Eusebius's words) the 'murderers' of Christ, whose death was commemorated within the walls of that same 'New Jerusalem' through the inclusion of the traditional site of Golgotha within its inner courtyard.

Our investigation has revealed Golgotha to be a site of some significance for JewishChristian relations and for the development of competing traditions. Commemorative activity related to the site of Jesus's death at Golgotha could be potentially charged with anti-Jewish rhetoric and sentiments,

48 Thanks are due to Halvor Moxnes for this suggestion. as we have seen in the form of Eusebius's 'New Jerusalem' ideology. Writing in the second century, well before the construction of the Church of Holy Sepulchre, Melito, the bishop of Sardis, uses the traditional location of Golgotha in the middle of the city of Jerusalem to further his rhetorical indictment of 'Israel', saying that Jesus was 'murdered' in the middle of Jerusalem specifically by 'Israel' (Peri Pascha 72, cf. 93, 94). Egeria describes a commemorative Good Friday service that took place at the traditional site of Golgotha in the late fourth century (Itinerarium Egeriae 37.5-7), which revolved around public readings of New Testament Passion narratives. These readings elicited an extreme emotional response, such that Egeria relates that 'there is no one, either older or younger, who on that day in those three hours does not bewail more than can be reckoned that the Lord has suffered those things for us' (Itinerarium Egeriae 37.7). ${ }^{49}$ While Egeria's statement and description are not anti-Jewish in themselves, when we combine the sort of emotional commemorative activity that Egeria describes surrounding the death of Jesus with the notion that Jews were the 'murderers' of Jesus, as we have seen in the writings of Melito and Eusebius, it is easy to imagine just how potent the resulting anti-Jewish rhetoric and symbolism could be.

In light of this, the rise of competing locations for the burial of Adam in Jewish tradition at either Hebron or Mount Moriah, over against Golgotha, makes very good sense. Even if these traditions arose prior to our earliest-known instantiations of the Golgotha tradition, or to the construction of the Church of the Holy Sepulchre, they still could have, and probably did,

49 Translation from McGowan and Bradshaw 2018: 178 . 
function as competing Jewish alternatives to the Golgotha tradition. The apparent circulation of the Kiryat Arba tradition in the late fourth century probably functioned in this way, whether or not that was when it first emerged. As discussed above, these traditions did not appear nor circulate in vacuums, and there is good evidence that ancient authors could be aware of different Adamic burial traditions, and could use, develop, combine, or reject them to suit their purposes.

The 'codification', so to speak, of the tradition of Adam's burial at Golgotha through the construction of the Chapel of Adam within the Church of the Holy Sepulchre during the time of Modestus in the seventh century (Taylor I 993: I 32-4; Coüasnon I 974: 50; Jeremias I 926b: 78) could potentially be understood in part as another phase in the competitive traditioning process. Whereas the Adam-Golgotha tradition had previously existed in oral and written form, with the construction of the Chapel of Adam, the oral and written Adam traditions crystallised and were given concrete, tangible witness in architectural form. While the traditional site of Golgotha existed in the courtyard of the Church of the Holy Sepulchre right from its construction, it was not until the construction of the Chapel of Adam in the seventh century that the tradition of Adam's burial was given 'official' architectural codification. This tradition has continued to capture the Christian imagination throughout the ages, whether through the iconography of the skull of Adam at the foot of Jesus's cross in artwork depicting the crucifixion from the medieval period on (Bagatti I977), or through the ongoing use of the Chapel of Adam, which is visited by countless pilgrims to this day. In the words of Jonathan Z. Smith, 'In Jerusalem, story, ritual, and place could be one' (Smith 20I0: 86).

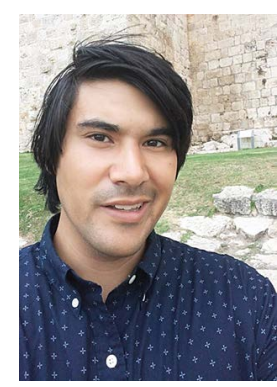

Jordan J. Ryan, Ph.D., McMaster University 2016, is Assistant Professor of New Testament at Wheaton College, where he teaches in the Biblical Studies and Archaeology programs. $\mathrm{He}$ is a staff member of the Tel Shimron excavation, and has previously also been a member of the excavations at Magdala. His recent research has focused primarily on ancient synagogues and on early commemorative churches.

\section{Primary sources}

Johnson, M. D. I983. 'Life of Adam and Eve: a new translation and introduction', in The Old Testament Pseudepigrapha, ed. James J. Charlesworth, vol. 2 (Peabody: Hendrickson), 249-95.

McGowan, Anne, and Paul F. Bradshaw. 2018. The Pilgrimage of Egeria: A New Translation of the Itinerarium Egeriae with Introduction and Commentary (Collegeville: Liturgical Press).

$\mathrm{McVey}$, Kathleen E. (trans.). I 989 . Ephrem the Syrian: Hymns. Classics of Western Spirituality (New York: Paulist Press).

Menk, Otto, and Merin Meiser. I 998. Das Leben Adams und Evas. Jüdische Schriften aus hellenistisch-römischer Zeit 5:2 (Gütersloher Verlagshaus).

Tromp, Johannes. 2005. The Life of Adam and Eve in Greek: A Critical Edition. Pseudepigrapha Veteris Testamenti Graece (Leiden: Brill).

-2016. The Life of Adam and Eve in Greek: A Critical Edition. Pseudepigrapha Veteris Testamenti Graece 6 (Atlanta: SBL).

VanderKam, James C. 2018. Jubilees: A Commentary in Two Volumes. Hermeneia (Minneapolis, MN: Fortress).

Wallraff, M. (ed.). 2007. Julius Africanus, Chronographiae (Berlin and New York: De Gruyter).

Wilkinson, John. I 999. Egeria's Travels to the Holy Land (Warminster: Aris \& Phillips).

Williams, Frank (trans.). 2009. The Panarion of Epiphanius of Salamis, and edn (Leiden: Brill).

\section{Bibliography}

Adelman, Rachel. 2009. The Return of the Repressed: Pirqe De-Rabbi Elizer and the Pseudepigrapha, Journal for the Study of 
Judaism: Supplement Series I 40 (Leiden: Brill).

Africanus, Julius. 2007. Chronographiae, ed. Martin Wallraff. Die Grieschischen Christlichen Schriftsteller der ersten Jahrhunherte Neue Folge I 5 (Berlin: Walter de Gruyter).

Alexander, Philip S. 1997. 'Jerusalem as the omphalos of the world: on the history of a geographical concept', Judaism 46(2): I 47-58.

Bagatti, Bellarmino. 1977. 'Note sull'iconografia di Adamo sotto il Calvario', Liber Annuus 27: 5-32.

Bagatti, Bellarmino, and Emmanuel Testa. I 978. Il Golgota e la Croce: ricerche storicoarcheologiche. Collectio minor 2 I (Jerusalem: Franciscan Printing Press).

Coüasnon, Charles. I 974. The Church of the Holy Sepulchre in Jerusalem (London: Oxford University Press).

Dow, Lois Katherine. 2008. 'Eternal Jerusalem: Jerusalem/Zion in Biblical Theology with Special Attention to "New Jerusalem" as the Name for the Final State in Revelation 2 I-2 2', Ph.D. dissertation, McMaster Divinity College.

Finkelstein, Ari. 201 8. The Specter of the Jerws: Emperor Julian and the Rhetoric of Ethnicity in Syrian Antioch (Oakland: University of California Press).

Fremantle, W. H. I 892. St. Jerome: Letters and Select Works. Nicene and Post-Nicene Fathers, Series 2, vol. 6 (New York: Christian Literature Publishing).

Gafni, Isaiah M. 20 I 9. Jerws and Judaism in the Rabbinic Era: Image and Reality - History and Historiography. Texts and Studies in Ancient Judaism I 73 (Tübingen: Mohr Siebeck).

Gibson, Shimon, and Joan E. Taylor. I 994. Beneath the Church of the Holy Sepulchre, Jerusalem: The Archaeology and Early History of Traditional Golgotha (London: Palestine Exploration Fund).

Gonen, Rivka. 2003. Contested Holiness: Jewish, Muslim, and Christian Perspectives on the Temple Mount in Jerusalem (Jersey City, NJ: Ktav).

Grypeou, Emmanouela, and Helen Spurling. 2013. The Book of Genesis in Late Antiquity: Encounters Between Jewish and Christian Exegesis. Jewish and Christian Perspectives 24 (Leiden: Brill).

Hanson, R. P. C. 2004. Origen's Doctrine of Tradition, reprint (Eugene, OR: Wipf and Stock).

Heine, Ronald E. 2002. The Commentaries of
Origen and Jerome on St. Paul's Epistle to the Ephesians. Oxford Early Christian Studies (Oxford University Press).

- (trans.). 2018. Origen on the Gospel of St. Matthew. Oxford Early Christian Texts, vol. 2 (Oxford University Press).

Horst, Pieter W. van der. 20 I 4. Studies in Ancient Judaism and Early Christianity. Ancient Judaism \& Early Christianity 87 (Leiden and Boston: Brill).

Jacobs, Andrew S. 2or6. Epiphanius of Cyprus: A Cultural Biography of Late Antiquity (Oakland: University of California Press).

Jeremias, Joachim. I 926a. Golgotha. АГГЕ $\Lambda \mathrm{O} \Sigma$, I (Leipzig: E. Pfeiffer).

- r 926b. 'Golgotha und der heilige Felsen', АГГЕ $\Lambda \mathrm{O} \Sigma, 2: 74^{-\mathrm{I}} 28$.

Jonge, Marinus de. 2000. 'The literary development of the Life of Adam and Eve', in Literature on Adam and Eve: Collected Essays, ed. Gary Anderson, Michael Stone, and Johannes Tromp. Studia in Veteris Testamenti Pseudepigrapha (Leiden: Brill), 239-50. -2003. Pseudepigrapha of the Old Testament as Part of Christian Literature: The Case of the Testaments of the Trwelve Patriarchs and the Greek Life of Adam and Eve. Studia in Veteris Testamenti Pseudepigrapha i 8 (Leiden: Brill).

Jonge, Marinus de, and Johannes Tromp. I 997. The Life of Adam and Eve and Related Literature. Guides to Apocrypha and Pseudepigrapha (Sheffield Academic).

Kelley, Justin L. 201 9. The Church of the Holy Sepulchre in Text and Archaeology: A Survey and Analysis of Past Excavations with a Collection of Principal Historical Sources (Oxford: Archaeopress).

Kadari, Adiel. 2016. 'Interreligious aspects in the burial of Adam in Pirkei de-Rabbi Eliezer', in Religious Stories in Transformation: Conflict, Revision and Reception, ed. Alberdina Houtman, Tamar Kadari, Marcel Poorthuis and Vered Tohar. Jewish and Christian Perspectives 3 I (Leiden: Brill), 82-IO3.

Kelly, John Norman Davidson. I 975 . Jerome: His Life, Writings, and Controversies (New York: Duckworth).

Kretschmar, Georg. I 987. 'Festkalender und Memorialstatten Jerusalems in altkirchlicher Zeit', in Jerusalemer Heiligtumstraditionen in altkirchlicher und frubislamischer Zeit, ed. Heribert Busse and Gerog Kretschmar. Abhandlungen des Deutschen 
Palastinavereins 8 (Wiesbaden: Otto

Harrassowitz), 29-I I I.

Krewson, William L. 2017. Jerome and the Jerws: Innovative Supersessionism (Eugene, OR: Wipf and Stock).

Laato, Anni Maria. 20 I4. 'What makes the Holy Land holy? A debate between Paula, Eustochium, and Marcella (Jerome, Ep. 46)', in Holy Places and Cult, ed. Erkki Koskenniemi and J. Cornelis de Vos. Studies in the Reception History of the Bible 5 (Winona Lake: Eisenbrauns), I69-99.

Laato, Antti. 20 I8. 'Funeral ritual of Adam and Abel in GLAE: confronting Gnostic theology', in Life of Adam and Eve: Using Jewish Traditions and Confronting Gnostic Reversed Exegesis, eds. Antti Laato and Lotta Valve. Studies in the Reception History of the Bible 9 (University Park, PA: Penn State Press), 67-92.

Leonhard, Clemens. 200r. 'Observations on the date of the Syriac Cave of Treasures', in The World of the Aramaeans: Studies in Honour of Paul-Eugène Dion, vol. 3, ed. P. M. Michèle Daviau, John W. Wevers, and Michael Weigl. Journal for the Study of the Old Testament: Supplement Series 326 (Sheffield Academic), 25593.

Lipatov-Chicherin, Nikolai. 20 I9. 'Early

Christian tradition about Adam's burial on Golgotha and Origen', in Origeniana Duodecima: Origen's Legacy in the Holy Land. A Tale of Three Cities: Jerusalem, Caesarea and Bethlehem. Proceedings of the 12th International Origen Congress, Jerusalem, 25-29 June, 2017, ed. Brouria Bitton-Ashkelony, Oded Irshai, Aryeh Kofsky, H. Newman, and Lorenzo Perrone (Leuven: Peeters), I 5 I -78 .

Mancini, Ignazio. i 965 . 'Adamo sotto il Calvario', Terra Santa, 41: 277-82.

- 984 . Archeological Discoveries Relative to the Judeo-Christians (Jerusalem: Franciscan Printing Press).

Minov, Sergey. 2017. 'Date and provenance of the Syriac Cave of Treasures: a reappraisal', Hugoye 2O(I): I 29-2 29.

Nautin, Pierre. 1979. 'La date des commentaires de Jérôme sur les épîtres pauliniennes', Revue d'histoire ecclésiastique de Louvain 74(I): 5-I 2.

Nir, Rivka. 2004. 'The aromatic fragrances of Paradise in the Greek Life of Adam and Eve and the Christian origin of the composition', Novum Testamentum 46(I): 20-45.

Patrich, Joseph. 1993. 'The early Church of the
Holy Sepulchre in the light of excavations and restoration', in Ancient Churches Revealed, ed. Yoram Tsafrir (Jerusalem: Israel Exploration Society), IOI-I 7 .

Peterson, William L. 2008. 'Tatian the Assyrian', in A Companion to Second-Century Christian 'Heretics', ed. Antti Marjanen and Petri Luomanen (Leiden: Brill), I 25-58.

Shalev-Hurvitz, Vered. 20 1 5. Holy Sites Encircled: The Early Byzantine Concentric Churches of Jerusalem. Oxford Studies in Byzantium (Oxford University Press).

Skarsaune, Oskar. 2002. In the Shadow of the Temple: Jewish Influences on Early Christianity (Downers Grove, IL: IVP Academic).

Smit, Peter-Ben. 2004. 'Incense revisited: reviewing the evidence for incense as a clue to the Christian provenance of the Greek Life of Adam and Eve', Novum Testamentum 46(4): $369-75$.

Smith, Jonathan Z. 2010. To Take Place: Toward Theory in Ritual (University of Chicago Press).

Sweet, Anne Marie. I 992. 'A Religio-Historical Study of the Greek Life of Adam and Eve', Ph.D. dissertation, CITY University of Notre Dame.

Taylor, Joan E. I 993. Christians and the Holy Places: The Myth of Jewish-Christian Origins (Oxford University Press).

Tromp, Johannes. 2002. 'The textual history of the Life of Adam and Eve in the light of a newly discovered Latin text-form', Journal for the Study of Judaism in the Persian, Hellenistic, and Roman Periods 33(I): 28-4I.

Wilkinson, John. I 993. 'Constantinian churches in Palestine', in Ancient Churches Revealed, ed. Yoram Tsafrir (Jerusalem: Israel Exploration Society), 23-7.

2002. Jerusalem Pilgrims before the Crusades (Warminster: Aris \& Phillips).

20I 5. Jerusalem Pilgrims before the Crusades (Warminster: Aris \& Phillips).

Zemler-Cizewski, Wanda. 2004. 'The Apocryphal life of Adam and Eve: recent scholarly work', Anglican Theological Review 86(4): 67I-7. 